\title{
Temperature-induced changes in the cell-wall components of Mycobacterium thermoresistibile
}

\author{
Laurent Kremer, ${ }^{1}$ Yann Guérardel, ${ }^{2}$ Sudagar S. Gurcha, ${ }^{3}$ Camille Locht ${ }^{1}$ \\ and Gurdyal S. Besra ${ }^{3}$
}

1 Laboratoire des Mécanismes Moléculaires de la Pathogénie Microbienne, INSERM U447, Institut Pasteur de Lille/IBL, 1 rue du Pr. Calmette, BP245-59019 Lille Cedex, France

2 Laboratoire de Glycobiologie Structurale et Fonctionnelle, CNRS UMR8576, Université des Sciences et Technologies de Lille, F-59655 Villeneuve d'Ascq Cedex, France

${ }^{3}$ School of Biosciences, The University of Birmingham, Edgbaston, Birmingham B15 2TT, UK
Author for correspondence: Laurent Kremer. Tel: +33 3208711 54. Fax: +33 320871158. e-mail: laurent.kremer@ibl.fr

The mycobacterial cell wall consists of a core composed of peptidoglycan linked to the heteropolysaccharide arabinogalactan, which in turn is attached to mycolic acids. A variety of free lipids complements the mycolyl residues, whereas phosphatidylinositol mannosides (PIMs), lipoarabinomannan and proteins are interspersed in this framework. As a consequence, the cell envelope is extremely rich in lipids and early work has shown that the lipid content may vary with environmental conditions. To extend these studies, the influence of growth temperature on cell envelope components in Mycobacterium thermoresistibile, a temperature-resistant mycobacterial species, was investigated. Mycolic acid synthesis was reduced at $55^{\circ} \mathrm{C}$ compared to $37{ }^{\circ} \mathrm{C}$ and the production of fatty acids, presumably precursors of mycolic acids, was increased. Since fatty acids are elongated by the type II fatty acid synthase complex and consequently by a mycobacterial $\beta$-ketoacyl acyl carrier protein synthase (KasA), leading to mycolic acids, the expression level of KasA was analysed by Western blotting. KasA expression was significantly decreased at $55^{\circ} \mathrm{C}$ over $37^{\circ} \mathrm{C}$. Important changes in the mycolic acid composition were observed and characterized by reduced levels of cyclopropanation and the concomitant accumulation of the cis-olefin derivatives. In addition, striking differences involved in complex lipid composition, including acylated trehaloses and trehalose dimycolate (TDM) were also observed. At $55{ }^{\circ} \mathrm{C}, M$. thermoresistibile produced less TDM than at $37^{\circ} \mathrm{C}$, which could be explained by the down-regulation of antigen 85 (Ag85) expression as shown by Western blotting. The Ag85 complex represents a family of proteins known to catalyse the transfer of mycolates to trehalose, thereby generating TDM. Furthermore, at $55^{\circ} \mathrm{C}$ the level of phosphatidylinositol hexamannoside (PIM ${ }_{6}$ ) synthesis, but not that of other PIM species, was dramatically reduced. This observation could be correlated to a decrease of mannosyltransferase activity associated with membranes prepared from cells grown at $55^{\circ} \mathrm{C}$ as compared to $37^{\circ} \mathrm{C}$. Altogether, this study suggests that mycobacteria are capable of inducing important cell-wall changes in response to temperature variations, which may represent a strategy developed by the bacteria to adapt to environmental changes.

Keywords: mycobacteria, fatty acid synthase II, mycolic acid, KasA, temperature

Abbreviations: AcpM, mycobacterial acyl carrier protein; AG, arabinogalactan; FAME, fatty acid methyl ester; FAS, fatty acid synthase; KasA, $\beta$-ketoacyl AcpM synthase A; LAM, lipoarabinomannan; LM, lipomannan; MAME, mycolic acid methyl ester; PIM, phosphatidylinositol mannoside; PPM, polyprenol monophosphoryl mannose; TDM, trehalose dimycolate. 


\section{INTRODUCTION}

The mycobacterial cell envelope and its associated components have been implicated as direct modulators of key interactions between mycobacteria and their environment (Daffé \& Draper, 1998). However, very little is known about the mechanisms by which mycobacteria modulate expression of cell-wall components in response to changes in their environment, such as oxidative stress, growth, anaerobiosis, nutrient deprivation and temperature shifts. In bacteria, optimization of membrane function at various temperatures depends on a close regulation of membrane fluidity (Magnuson et al., 1993). For instance, Escherichia coli adjusts its fatty acid composition in response to lower temperature by increasing the amount of cis-vaccenic acid and decreasing the amount of palmitic acid incorporated into membrane phospholipids (Marr \& Ingrahm, 1962).

The mycobacterial cell envelope differs substantially from the canonical cell-wall structures of Gram-negative and Gram-positive bacteria (Brennan \& Nikaido, 1995). In addition to the typical cell-membrane bilayer and peptidoglycan layers found in other bacteria, the mycobacterial cell envelope contains mycolic acids covalently attached to arabinogalactan (AG) and a wide range of non-covalently attached complex lipids and glycolipids (Minnikin, 1982). Some of these lipids also exhibit potent biological activities and thus may be considered as important virulence factors (Cox et al., 1999; Camacho et al., 2001). Interestingly, some of them are exported and can be found within the cytoplasm of host macrophages, dissociated from the intact bacilli (Beatty et al., 2000). It has been proposed that the chemical diversity of lipids and glycolipids found in the mycobacterial cell envelope mediates specific interactions with host ligands or membranes rather than being solely responsible for the hydrophobicity and rigidity of the mycobacterial cell wall.

The capacity of pathogenic mycobacteria to survive and replicate within the hostile environment of the host macrophage depends on the existence of adaptive mechanisms of bacterial cell physiology. Although environmental adaptation of the mycobacterial cell wall and its components remains largely unknown, it is very likely that they participate in the adaptive process. The first evidence for this kind of regulatory process came from work conducted by Davidson et al. (1982) in Mycobacterium microti, a close relative of Mycobacterium tuberculosis. It was shown that young growing cultures harvested from mouse lungs contained high proportions of ketomycolates, whereas stationary phase cultures had roughly equal proportions of keto- and methoxymycolates. The proportion of $\alpha$-mycolates increased slightly with the age of the culture, but was always less than one-third of the total mycolate content. More recently, Yuan et al. (1998) reported that ketomycolates were produced more predominantly during intracellular growth of M. tuberculosis within THP-1 macrophages. These authors also demonstrated that the ratio of methoxymycolates to ketomycolates was altered by oxygen tension and that the ratio produced under low oxygen tension was identical to that of organisms grown in vivo.

In this report, we describe the effect of growth temperature on mycolic acid, fatty acid and complex lipid composition in Mycobacterium thermoresistibile. The rationale of the use of this strain is that it survives and replicates at elevated temperatures (up to $55^{\circ} \mathrm{C}$ ) compared to most mycobacterial species, a property that facilitates the analysis of cell-wall component changes induced by growth at high temperature.

\section{METHODS}

Strain and media. M. thermoresistible ATCC 19527 was usually grown at $37^{\circ} \mathrm{C}$ under constant shaking in Sauton medium supplemented with $10 \%$ OADC (Difco). Cultures grown at $55^{\circ} \mathrm{C}$ were obtained by shifting the temperature progressively from $37^{\circ} \mathrm{C}$ to $55^{\circ} \mathrm{C}$. Colony-forming units were plated on Middlebrook $7 \mathrm{H} 11$ solid media and incubated at $37^{\circ} \mathrm{C}$ for $3-4$ days.

Mycolic acid and fatty acid profiles of cells grown at high temperature. $\left[1,2-{ }^{14} \mathrm{C}\right]$ Acetate $\left[50-62 \mathrm{mCi} \mathrm{mmol}^{-1}(1 \cdot 85-\right.$ $\left.2.29 \mathrm{GBq} \mathrm{mmol}^{-1}\right)$; Amersham] was added at $1 \mu \mathrm{Ci} \mathrm{ml}^{-1}$ $\left(37 \mathrm{kBq} \mathrm{ml}^{-1}\right)$ to mycobacterial cultures grown at midexponential phase, followed by a further $6 \mathrm{~h}$ incubation at either $37^{\circ} \mathrm{C}$ or $55^{\circ} \mathrm{C}$. ${ }^{14} \mathrm{C}$-Labelled cells were harvested by centrifugation at $2000 \mathrm{~g}$ and washed once with PBS. Washed cells were then subjected to alkaline hydrolysis using $2 \mathrm{ml}$ $15 \%$ tetrabutylammonium hydroxide (TBAH) at $100{ }^{\circ} \mathrm{C}$ overnight and mixed with $4 \mathrm{ml} \mathrm{CH}_{2} \mathrm{Cl}_{2}, 300 \mu \mathrm{CH}_{3} \mathrm{I}$ and $2 \mathrm{ml}$ $\mathrm{H}_{2} \mathrm{O}$ for $1 \mathrm{~h}$. The upper aqueous phase was discarded and the lower organic phase was washed twice with water and dried. The lipids were extracted using diethyl ether, re-dried and resuspended in $200 \mu \mathrm{l} \mathrm{CH}_{2} \mathrm{Cl}_{2}$. An aliquot of the resultant mixture of fatty acid methyl esters (FAMEs) and mycolic acid methyl esters (MAMEs) was then subjected to TLC using silica gel plates (5735 silica gel $60 \mathrm{~F}_{254}$; Merck) developed in petroleum ether/acetone $(19: 1, \mathrm{v} / \mathrm{v})$. The FAMEs were separated by reverse-phase TLC on $\mathrm{C}_{18}$-silica gel plates (Sigma) using chloroform/methanol $(2: 3, \mathrm{v} / \mathrm{v})$.

In some instances, the individual MAMEs were resolved through two-dimensional silver ion argentation TLC by immersing $80 \%$ of a square silica gel TLC plate into a $10 \%$ $(\mathrm{w} / \mathrm{v})$ aqueous silver nitrate solution. Following air-drying, plates were activated at $100{ }^{\circ} \mathrm{C}$ for $1 \mathrm{~h} .{ }^{14} \mathrm{C}$-Labelled samples were run in the first dimension along the narrow strip without silver impregnation by developing twice with hexane/ethyl acetate $(19: 1, \mathrm{v} / \mathrm{v})$. The plates were then dried, turned 90 degrees and run into the silver layer by developing three times with petroleum ether/diethyl ether $(17: 3, \mathrm{v} / \mathrm{v})$. Autoradiograms were obtained by exposure to Kodak X-Omat AR film to reveal $\left[{ }^{14} \mathrm{C}\right]$ FAMEs and $\left[{ }^{14} \mathrm{C}\right]$ MAMEs.

Systematic analysis of complex mycobacterial lipids. The lipid composition was analysed using $\left[1,2-{ }^{14} \mathrm{C}\right]$ acetate-labelled M. thermoresistibile cells. Lipids were extracted by adding $2 \mathrm{ml} \mathrm{CH} \mathrm{CH}_{3} \mathrm{OH} / 0 \cdot 3 \% \mathrm{NaCl}(10: 1, \mathrm{v} / \mathrm{v})$ and $1 \mathrm{ml}$ petroleum ether to pelleted cells. After centrifugation, the upper petroleum ether layer was removed and $1 \mathrm{ml}$ petroleum ether was added. The combined petroleum ether extracts were then evaporated under nitrogen to yield apolar lipids that were resuspended in $\mathrm{CH}_{2} \mathrm{Cl}_{2}$ prior to TLC analysis. For extraction of polar lipids, the methanolic saline extract was heated at 
$65{ }^{\circ} \mathrm{C}$ for $5 \mathrm{~min}$ and $2 \cdot 3 \mathrm{ml} \mathrm{CHCl}_{3} / \mathrm{CH}_{3} \mathrm{OH} / 0 \cdot 3 \% \mathrm{NaCl}$ $(9: 10: 3$, by vol.) was added to the extract and mixed on a tube rotator for $10 \mathrm{~min}$. The solvent extract was then separated from the biomass by centrifugation and the supernatant retained. The pellet was further extracted with $0.75 \mathrm{ml}$ $\mathrm{CHCl}_{3} / \mathrm{CH}_{3} \mathrm{OH} / 0 \cdot 3 \% \mathrm{NaCl}(5: 10: 4$, by vol.) for $10 \mathrm{~min}$. The combined solvent extracts were mixed with $1.3 \mathrm{ml} \mathrm{CHCl}_{3}$ and $1.3 \mathrm{ml} 0.3 \% \mathrm{NaCl}$ for $5 \mathrm{~min}$. After centrifugation the lower organic layer was collected and evaporated to dryness to yield the polar lipids which were resuspended in $\mathrm{CHCl}_{3} / \mathrm{CH}_{3} \mathrm{OH} /$ $\mathrm{H}_{2} \mathrm{O}(10: 10: 3$, by vol.) prior to TLC analysis.

The complex lipids were analysed by two-dimensional TLC using a variety of solvent systems. Five systems were necessary to cover the polarity range of both non-polar and polar mycobacterial lipids (Besra, 1998): briefly, system A, first dimension, petroleum ether/ethyl acetate $98: 2, \mathrm{v} / \mathrm{v}(\times 3)$; second dimension, petroleum ether/acetone $(49: 1, \mathrm{v} / \mathrm{v})$; system $\mathrm{B}$, first dimension, petroleum ether/acetone $23: 2 \mathrm{v} / \mathrm{v}$ $(\times 3)$; second dimension, toluene/acetone $(19: 1, \mathrm{v} / \mathrm{v})$; system $\mathrm{C}$, first dimension, $\mathrm{CHCl}_{3} / \mathrm{CH}_{3} \mathrm{OH}(24: 1, \mathrm{v} / \mathrm{v})$; second dimension, toluene/acetone $(4: 1, \mathrm{v} / \mathrm{v})$; system $\mathrm{D}$, first dimension, $\mathrm{CHCl}_{3} / \mathrm{CH}_{3} \mathrm{OH} / \mathrm{H}_{2} \mathrm{O}$ (100:14:0 $\cdot 8$ by vol.); second dimension, $\mathrm{CHCl}_{3} /$ acetone $/ \mathrm{CH}_{3} \mathrm{OH} / \mathrm{H}_{2} \mathrm{O} \quad(50: 60: 2 \cdot 5: 3$ by vol.); and system E, first dimension, $\mathrm{CHCl}_{3} / \mathrm{CH}_{3} \mathrm{OH} / \mathrm{H}_{2} \mathrm{O}$ $\left(10: 5: 1\right.$, by vol.); second dimension, $\mathrm{CHCl}_{3} /$ acetic acid/ $\mathrm{CH}_{3} \mathrm{OH} / \mathrm{H}_{2} \mathrm{O}$ (40:25:3:6, by vol.). Lipids were detected by exposure of the TLCs to Kodak X-Omat AR film and charred at $110{ }^{\circ} \mathrm{C}$ following spraying with $\alpha$-naphthol or $5 \%$ molybdophosphoric acid.

Anti-KasA immune serum. Recombinant His-tagged $\beta$ ketoacyl mycobacterial ACP (AcpM) synthase (KasA) protein was produced in E. coli carrying pET28a-kas A and purified by affinity chromatography using a His-Trap column (Pharmacia) as described previously (Kremer et al., 2002a). Purified KasA was used to prepare an anti-KasA immune serum. A rat was injected four times with $25 \mu \mathrm{g}$ KasA mixed with an equal volume of adjuvant (monophosphoryl lipid A+trehalose dicorynomycolate; Sigma) at 1, 15, 30 and 60 days. The serum was collected at different time points after the last injection and the specificity of the antibodies was tested by Western blotting.

Electrophoresis and Western blot analyses. M. thermoresistibile cells were harvested, resuspended in PBS and disrupted by sonication. Protein concentration was determined on total lysates using the BCA Protein Assay Reagent kit (Pierce) according to the manufacturer's instructions. Twenty micrograms of total protein was subjected to SDS-PAGE as described by Laemmli (1970) with $12 \%$ acrylamide gels on a MiniProtean II system (Bio-Rad). Proteins were either stained with Coomassie blue R350 (Amersham Pharmacia) or transferred to nitrocellulose membranes for Western blot analysis (Kremer et al., 1995). For detection of KasA, membranes were incubated overnight with the rat anti-serum directed against KasA at a dilution of $1 / 500$, washed and subsequently incubated with anti-rat antibodies conjugated to alkaline phosphatase (Promega) used at a 1/7000 dilution. Detection of the antigen 85 (Ag85) complex was done by probing the membranes with a mixture of monoclonal antibodies $17 / 4$ and 32/4 diluted 1/10 (Huygen et al., 1994). Membranes were then incubated with anti-mouse antibodies coupled to alkaline phosphatase (Promega) and used at a 1/7000 dilution.

Incorporation of radiolabelled mannose (Man) from GDP$\left[{ }^{14} \mathrm{C}\right]$ Man into membrane lipids. The enzymically active membrane fraction of $M$. thermoresistible was prepared as previously described (Besra et al., 1997). To mannosylate endogenous polyprenol monophosphate lipid substrates, the membrane fractions were incubated in buffer A $[50 \mathrm{mM}$ MOPS (adjusted to $\mathrm{pH} 7.9$ with $\mathrm{KOH}$ ), $5 \mathrm{mM} \beta$-mercaptoethanol, $10 \mathrm{mM} \mathrm{MgCl}$ ] containing $0.1 \mathrm{mM}$ DTT, $20 \mathrm{mM}$ $\mathrm{NaF}, 2 \cdot 4 \mu \mathrm{M} \quad[0 \cdot 125 \mu \mathrm{Ci} \quad(4.62 \mathrm{kBq})]$ GDP-[U- $\left.{ }^{14} \mathrm{C}\right]$ mannose [321.4 $\mathrm{mCi} \mathrm{mmol}^{-1}(11.9 \mathrm{GBq})$ DuPont NEN] and $62.5 \mu \mathrm{M}$ ATP in a total volume of $50 \mu \mathrm{l}$ at $37^{\circ} \mathrm{C}$ for $30 \mathrm{~min}$. The reaction was terminated by the addition of $4 \mathrm{ml} \mathrm{CHCl}_{3} /$ $\mathrm{CH}_{3} \mathrm{OH} / 0.8 \mathrm{M} \mathrm{NaOH}(10: 10: 3$, by vol.) and was followed by incubation at $55^{\circ} \mathrm{C}$ for $15 \mathrm{~min}$. The reaction mixture was cooled and $1.75 \mathrm{ml} \mathrm{CHCl}_{3}$ and $0.75 \mathrm{ml} \mathrm{H}_{2} \mathrm{O}$ were added. After centrifugation the upper aqueous phase was discarded. The lower phase was washed three times with $2 \mathrm{ml} \mathrm{CHCl}_{3} /$ $\mathrm{CH}_{3} \mathrm{OH} / \mathrm{H}_{2} \mathrm{O}(3: 47: 48$, by vol.) to yield an organic fraction, which contained exclusively the mild-alkali stable family of polyprenol monophosphoryl mannoses (PPMs). This fraction was then dried under a stream of nitrogen and resuspended in $200 \mu \mathrm{CHCl}_{3} / \mathrm{CH}_{3} \mathrm{OH}(2: 1, \mathrm{v} / \mathrm{v})$. PP $\left[{ }^{14} \mathrm{C}\right] \mathrm{Ms}$ were quantified by scintillation counting and equal aliquots (4000 c.p.m.) were resolved by TLC on silica gel plates using $\mathrm{CHCl}_{3} / \mathrm{CH}_{3} \mathrm{OH} /$ $\mathrm{H}_{2} \mathrm{O}$ (65:25:4, by vol.). Autoradiograms were obtained by exposing the chromatograms to Kodak X-Omat AR films for 2-3 days.

To assess the transfer of $\left[{ }^{14} \mathrm{C}\right] \mathrm{Man}$ from GDP- $\left[{ }^{14} \mathrm{C}\right] \mathrm{Man}$ to the phosphatidylinositol mannosides (PIMs), membrane fractions were incubated in buffer A containing $0.1 \mathrm{mM}$ DTT, $20 \mathrm{mM}$ $\mathrm{NaF}, 62.5 \mu \mathrm{M}$ ATP, $10 \mathrm{mM} \mathrm{CaCl}_{2}$ and $2.5 \mu \mathrm{g}$ amphomycin (a lipopeptide antibiotic that specifically inhibits polyprenylphosphate-requiring translocases and the synthesis of $\mathrm{C}_{35} / \mathrm{C}_{50}$ P-Man) in a total volume of $50 \mu \mathrm{l}$. Reactions were incubated for $10 \mathrm{~min}$ at $37^{\circ} \mathrm{C}$ prior to the addition of $2.4 \mu \mathrm{M}(0.125 \mu \mathrm{Ci})$ GDP-[U- $\left.{ }^{14} \mathrm{C}\right] \mathrm{Man}$, and held at $37{ }^{\circ} \mathrm{C}$ for a further $50 \mathrm{~min}$. The reaction was stopped by the addition of $4 \mathrm{ml} \mathrm{CHCl}_{3} /$ $\mathrm{CH}_{3} \mathrm{OH} / \mathrm{H}_{2} \mathrm{O}(10: 10: 3$, by vol.) and incubation at room temperature for $30 \mathrm{~min}$, followed by the addition of $1.75 \mathrm{ml}$ $\mathrm{CHCl}_{3}$ and $0.75 \mathrm{ml} \mathrm{H} \mathrm{H}_{2} \mathrm{O}$. The lower organic layer of the biphasic mixture was washed three times with $2 \mathrm{ml} \mathrm{CHCl}_{3} /$ $\mathrm{CH}_{3} \mathrm{OH} / \mathrm{H}_{2} \mathrm{O}$ (3:47:48, by vol.), dried under a stream of nitrogen and resuspended in $200 \mu \mathrm{CHCl}_{3} / \mathrm{CH}_{3} \mathrm{OH}(2: 1$, $\mathrm{v} / \mathrm{v})$. The transfer of $\left[{ }^{14} \mathrm{C}\right] \mathrm{Man}$ from GDP- $\left[{ }^{14} \mathrm{C}\right]$ Man to the PIMs was quantified by scintillation counting and the material was analysed by TLC-autoradiography as described previously (Besra et al., 1997).

\section{RESULTS}

\section{Growth of $M$. thermoresistibile at high temperature inhibits mycolic acid biosynthesis}

Bacteria alter the acyl chains of their membrane phospholipids in response to changes of environmental conditions (Cronan, 2002). The three major acyl-chain modifications all involve double bonds. First, desaturation can occur, where a double bond is introduced into a saturated acyl chain, and second, cis-trans isomerization can be observed. Third, in cyclopropane fatty acid synthesis, a methylene carbon may be added across the double bond to form a three-membered ring. We therefore asked whether temperature changes may also alter mycobacterial fatty acid and mycolic acid synthesis. Mycolic acids from $M$. thermoresistibile consist of three main subclasses, designated as $\alpha$-, methoxy- and ketomycolates, and a minor subclass of $\alpha^{\prime}$-mycolates (Levy-Frebault et al., 1986). The $\alpha$-, methoxy- and ketosubclasses consist of $\mathrm{C}_{72}-\mathrm{C}_{80}$ cyclopropanated/dienoic/ 


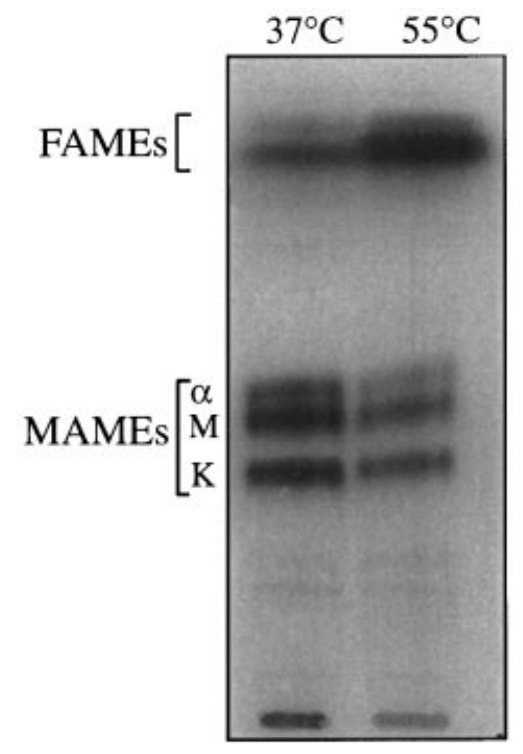

Fig. 1. Elevated growth temperature of $M$. thermoresistibile inhibits mycolic acid production and induces accumulation of fatty acids. Mycobacteria were grown in liquid medium either at $37^{\circ} \mathrm{C}$ or $55^{\circ} \mathrm{C}$ and labelled with $1 \mu \mathrm{Ci}(37 \mathrm{kBq}) \quad[1,2-$ ${ }^{14} \mathrm{C}$ ]acetate $\mathrm{ml}^{-1}$. Labelled lipids were extracted, derivatized and resolved by normal-phase TLC using petroleum ether/acetone $(19: 1, v / v)$. Equal counts (200000 c.p.m.) were loaded in each lane. $\alpha, M$ and $K$ indicate $\alpha$-, methoxy- and keto-MAMEs, respectively.

monoenoic acids, whereas the $\alpha^{\prime}$-mycolates are $\mathrm{C}_{60^{-}}$ monoenoic acids, due to their shorter meromycolic chain (Kremer et al., 2000). To determine the effect of growth temperature, M. thermoresistibile was grown either at $37^{\circ} \mathrm{C}$ or at $55^{\circ} \mathrm{C}$, labelled with $\left[{ }^{14} \mathrm{C}\right]$ acetate, and both FAMEs and MAMEs extracted and analysed by TLC and autoradiography. Surprisingly, a temperature shift to $55^{\circ} \mathrm{C}$ was associated with a dramatic decrease in $\alpha$-, methoxy- and ketomycolate synthesis (Fig. 1). The shorter $\alpha^{\prime}$-species cannot be resolved in the solvent system used in Fig. 1 and as a consequence we turned to a more complete resolution of MAME subfamilies using silver ion argentation chromatography as described below.

\section{Temperature alters the mycolic acid profile of M. thermoresistibile}

To determine whether a temperature shift also alters $\left[{ }^{14} \mathrm{C}\right]$ acetate-labelled MAMEs, we examined the MAME subfamilies by two-dimensional argentation TLC. This technique has been used previously for the analysis of M. tuberculosis MAMEs (George et al., 1995; Glickman et al., 2001). Briefly, the sample was developed in the first dimension along the un-impregnated strip to separate the mycolates by polarity. The plate is then developed in the second dimension (silver nitrate) to separate the mycolates by degree and type of unsaturation. Indeed, silver nitrate retards the migration of unsaturated lipids relative to saturated or cyclopropanated lipids. The TLC pattern of M. thermoresistibile grown at $37^{\circ} \mathrm{C}$ and $55^{\circ} \mathrm{C}$ is shown in Fig. 2. At $37^{\circ} \mathrm{C}$, $\alpha$-, methoxy- $(\mathrm{M})$ and ketomycolates $(\mathrm{K})$ were mainly present as cyclopropanated species along with a lower abundance of $\alpha^{\prime}$-mycolates. Minor species with the polarity of $\alpha$-, methoxy- and ketomycolates but which are retarded by silver impregnation probably correspond to cis- or trans-olefins. In contrast, at $55^{\circ} \mathrm{C}$, the degree of cyclopropanation was dramatically reduced, with the $\alpha$-mycolates giving rise to diunsaturated cis/cismycolates and the methoxymycolates being almost completely replaced by their cis-olefin precursor. Interestingly, the level of cyclopropanated ketomycolates remained unaffected. In addition, at $55^{\circ} \mathrm{C}$ a complete loss of trans-olefins for all mycolic acid subclasses was observed. Thus, elevated growth temperatures appear to result in the accumulation of cis-olefins containing

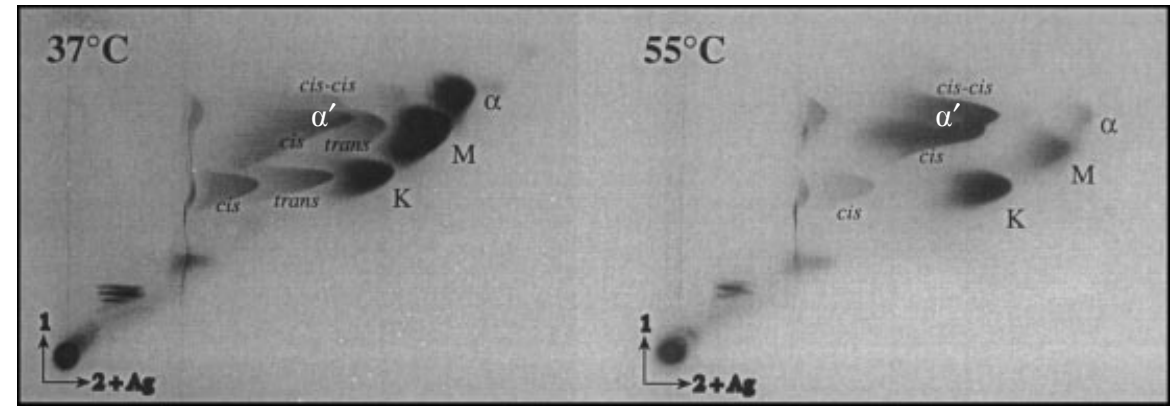

Fig. 2. Two-dimensional silver ion argentation autoradiographic TLC of $\left[1,2-{ }^{14} \mathrm{C}\right]$ acetate-labelled $M$. thermoresistibile. Cultures incubated either at $37{ }^{\circ} \mathrm{C}$ (left panel) or $55^{\circ} \mathrm{C}$ (right panel) were labelled with $\left[1,2-{ }^{14} \mathrm{C}\right]$ acetate. ${ }^{14} \mathrm{C}$-labelled FAMEs-MAMEs were isolated as described in Methods and 100000 c.p.m. of each extract applied to two-dimensional silver ion argentation TLC plates. The plates were developed in the first direction by using two developments of hexane/ethyl acetate $(19: 1, \mathrm{v} / \mathrm{v})$ and in the second direction by using a triple development of petroleum ether/diethyl ether $(17: 3, v / v) . \alpha, \alpha^{\prime}, M$ and $\mathrm{K}$ indicate $\alpha_{-}, \alpha^{\prime}-$, methoxy- and keto-MAMEs, respectively. Autoradiograms were obtained after 4 days exposure to Kodak X-Omat AR film. 


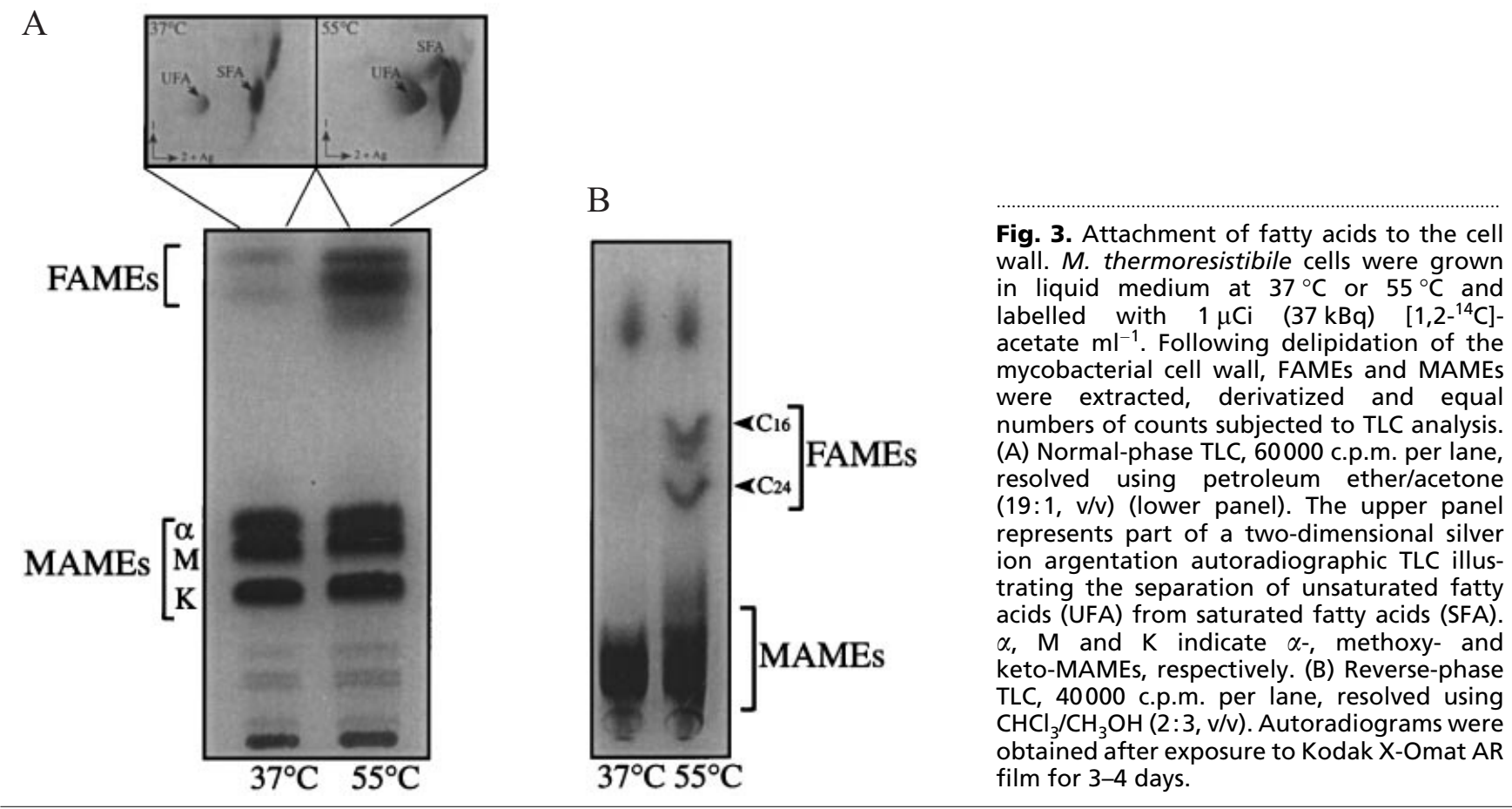

MAMEs, concomitant with the lack of cyclopropanated MAMEs.

\section{High-temperature growth of $M$. thermoresistibile causes accumulation of fatty acid synthase (FAS-I) end products and decreases of expression of enzymes involved in mycolic acid synthesis and transfer}

Since FAS-I is believed to generate FAS-II substrates (Kremer et al., 2000), one would expect that reduction of mycolic acid biosynthesis through FAS-II inhibition would cause accumulation of the FAS-I products. As shown in Fig. 1, growth at $55^{\circ} \mathrm{C}$ induces a strong production/accumulation of FAMES that are the end products of FAS-I. The in vitro activities of FAS-I from Mycobacterium smegmatis and Mycobacterium bovis BCG were characterized by Peterson \& Bloch (1977) and Kikuchi et al. (1992), respectively. A bimodal fatty acid pattern of $\mathrm{C}_{16}$ and $\mathrm{C}_{24}$ was reported for M. smegmatis, whilst $M$. bovis BCG possessed a bimodal fatty acid pattern of $\mathrm{C}_{16}$ and $\mathrm{C}_{26}$. Our analysis by reverse-phase TLC of the ${ }^{14} \mathrm{C}$-labelled FAMEs from $M$. thermoresistibile that accumulated at $55^{\circ} \mathrm{C}$ consisted mainly of $\mathrm{C}_{16}-\mathrm{C}_{24}$ fatty acids (data not shown).

To investigate whether the FAMEs accumulating at $55^{\circ} \mathrm{C}$ were associated to the cell wall or were present as free lipids, ${ }^{14} \mathrm{C}$-labelled cells were delipidated to extract free lipids. FAMEs and MAMEs were then isolated and analysed by TLC and autoradiography. As shown in Fig. 3(a) (lower panel), nearly all FAMEs from cells incubated at $37^{\circ} \mathrm{C}$ were removed after delipidation. In contrast, FAMEs were still present in delipidated cells and associated with isolated cell walls from bacilli grown at $55^{\circ} \mathrm{C}$ (Fig. 3a). In addition, two-dimensional argentation TLC clearly showed that both unsaturated and saturated FAMEs accumulated at $55^{\circ} \mathrm{C}$ and were associated with the cell wall. Reverse-phase TLC showed these FAMEs corresponded mainly to $\mathrm{C}_{16}-\mathrm{C}_{24}$ fatty acids (Fig. 3b).

We have assumed that the decrease of mycolic acid biosynthesis observed at $55^{\circ} \mathrm{C}$ may be linked to downregulation of FAS-II components. To test this hypothesis, Western blot analysis was performed to analyse KasA expression in M. thermoresistibile crude lysates since KasA has been shown to be part of the FAS-II system (Kremer et al., 2002a). Anti-KasA antibodies were generated against recombinant $M$. tuberculosis KasA. As shown in Fig. 4(a), the anti-KasA antibodies recognized the $M$. thermoresistibile protein. However, the KasA expression level was strongly reduced in extracts from cells grown at $55^{\circ} \mathrm{C}$. This result was found to be reproducible in several independent experiments. The genomic organization around the kas A locus in M. tuberculosis suggests an operon of five genes encoding several FAS-II components, namely fabD, acpM, kas A, kasB and accD6 (Cole et al., 1998). Thus, a temperature shift to $55^{\circ} \mathrm{C}$ may also, presumably, down-regulate the expression of the other genes encoded in the kas operon.

The Ag85 complex from M. tuberculosis consists of three abundantly secreted proteins ( $\mathrm{FbpA}, \mathrm{FbpB}, \mathrm{FbpC} 2$ ) that play a key role in the pathogenesis of tuberculosis (Wiker \& Harboe, 1992) and exhibit cell-wall mycolyltransferase activity. Belisle et al. (1997) and Kremer et al. 
B

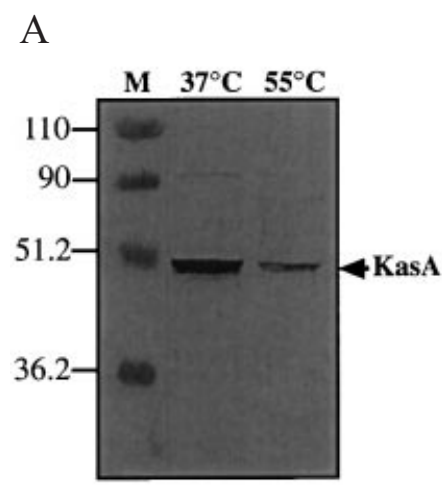

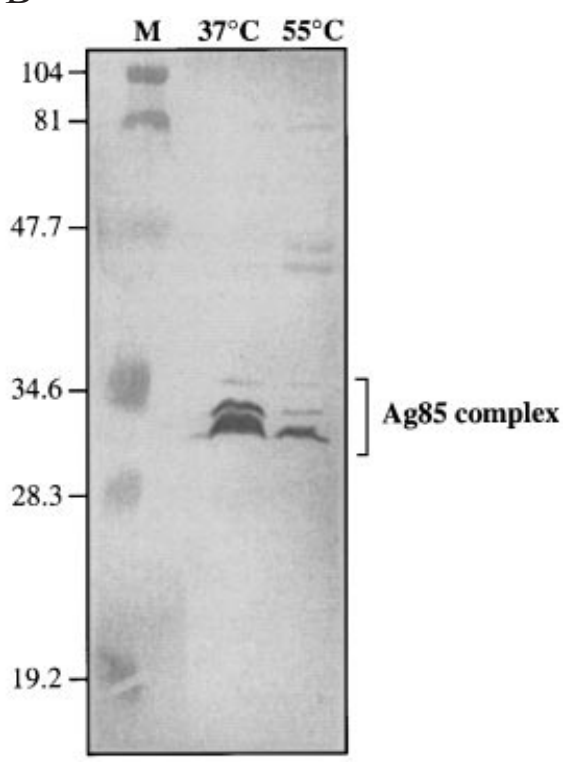

Fig. 4. Expression levels of KasA and the Ag85 complex by Western blot analysis. (A) Crude lysates (20 $\mu \mathrm{g}$ total protein) from M. thermoresistibile cultivated at $37^{\circ} \mathrm{C}$ or $55^{\circ} \mathrm{C}$ were resolved by $12 \%$ SDS-PAGE, transferred to a membrane and probed with a polyclonal rat antiserum raised against the $M$. tuberculosis KasA protein $(1 / 500$ dilution). (B) Crude lysates were resolved by $12 \%$ SDS-PAGE, transferred to a membrane and probed for the presence of the Ag85 complex. A mixture of the two monoclonal antibodies 17/4 and 32/4 (1/10 dilution) raised against the $M$. tuberculosis Ag85 complex was used. $\mathrm{M}$, pre-stained molecular standards. (2002b) demonstrated that all three purified M. tuberculosis antigens catalyse the transfer of mycolates to trehalose via a mycolyltransferase exchange process, leading to the formation of 6-trehalose monomycolate (TMM), 6,6'-trehalose dimycolate (TDM) and to the cell wall proper. Since mycolic acid biosynthesis is inhibited at elevated growth temperatures, we would expect a reduced expression of the Ag85 complex. Therefore, expression of the Ag85 complex was investigated by Western blot analysis using monoclonal antibodies directed against the M. tuberculosis Ag85 complex (Huygen et al., 1994). As shown in Fig. 4(b), expression was significantly reduced in a crude lysate from cells grown at $55^{\circ} \mathrm{C}$, compared to a lysate from cells grown at $37^{\circ} \mathrm{C}$. These results suggest that elevated temperatures affect the capacity of the cells to transfer mycolates to trehalose, ultimately leading to TDM (see below), presumably through down-regulation of the Ag85 complex.

\section{Temperature effects on other complex lipids}

Associated with the mycolic acid layer are a number of polar and apolar lipids which are thought to extend into the outer surface of the cell. This waxy coat of lipids may account for the limited permeability of mycobacteria as well as for their tendency to grow in large clumps and their natural resistance to toxic substances. The profound alteration of fatty acid and mycolic acid production observed at elevated growth temperature led us to investigate the cellular complex lipid profile by in vivo labelling and two-dimensional TLC analysis of the bacteria grown either at $37^{\circ} \mathrm{C}$ or at $55^{\circ} \mathrm{C}$. As shown in Fig. 5, the production of many cell-wall components, including diacylated trehalose, multiacylated trehaloses and glycerol monomycolate were altered. TDM, also called cord factor (Bloch, 1950), was found to be down- regulated at elevated temperature. This glycolipid has been widely implicated in characteristic pathogenic features of mycobacterial diseases, including granuloma formation (Bekierkunst, 1968).

Among other complex lipids whose expression was affected at $55^{\circ} \mathrm{C}$ were the PIMs (Fig. 5E). The two PIM 6 populations consisting of $\mathrm{Ac}_{4} \mathrm{PIM}_{6}$ and $\mathrm{Ac}_{3} \mathrm{PIM}_{6}$ were appreciably synthesized at $37^{\circ} \mathrm{C}$ as determined by twodimensional TLC after charring with $\alpha$-naphthol. Synthesis of both $\mathrm{Ac}_{4} \mathrm{PIM}_{6}$ and $\mathrm{Ac}_{3} \mathrm{PIM}_{6}$ was strongly inhibited at elevated temperature, whereas the expression of the other PIMs was not altered.

\section{Incorporation of GDP- $\left[{ }^{14} \mathrm{C}\right]$ Man by $M$. thermoresistibile membranes}

Simpler PIMs $\left(\mathrm{PIM}_{1}, \mathrm{PIM}_{2}, \mathrm{PIM}_{3}\right)$ originate from phosphatidyl inositol and GDP-Man, but further growth of the linear lipomannan backbone utilizes $\mathrm{C}_{35^{-}} / \mathrm{C}_{50}-\mathrm{P}-$ Man and is amphomycin-sensitive (Besra et al., 1997). Amphomycin treatment specifically disrupts the action of a variety of translocase enzymes, by chelating polyprenyl monophosphates in the presence of $\mathrm{Ca}^{2+}$, and inhibits the transfer of a range of monomeric units to polyprenyl-monophosphate carriers (Besra et al., 1997). Amphomycin was therefore used to measure the transfer of radiolabelled Man from GDP- $\left[{ }^{14} \mathrm{C}\right] \mathrm{Man}$ into membrane lipids. $\left[{ }^{14} \mathrm{C}\right] \mathrm{Man}$-labelled products were extracted from enzymically active membrane fractions that were incubated with GDP- $\left[{ }^{14} \mathrm{C}\right] \mathrm{Man}$. Incorporation was quantitatively lower with membrane fractions from M. thermoresistibile grown at $55^{\circ} \mathrm{C}$ compared to bacilli grown at $37^{\circ} \mathrm{C}$, suggesting decreased GDP-Mandependent mannosyltransferase activities at $55^{\circ} \mathrm{C}$ (data not shown). Analysis by TLC and autoradiography of the $\left[{ }^{14} \mathrm{C}\right]$ mannolipids formed showed that, with low 


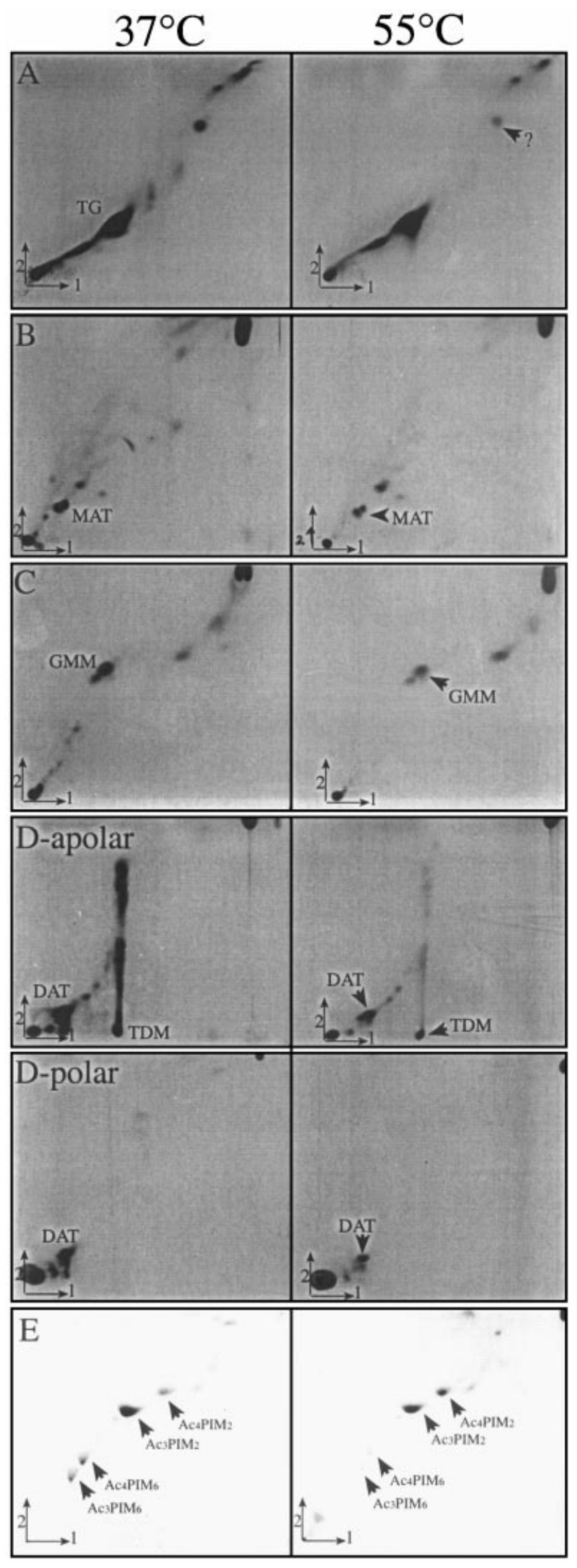

protein concentrations (up to $120 \mu \mathrm{g} \mathrm{ml}^{-1}$ ), PIM $_{2}$ was poorly synthesized by membranes prepared from cells grown at $55^{\circ} \mathrm{C}$ (Fig. 6a). In addition, synthesis of PIM was inhibited in membranes from cells grown at $55^{\circ} \mathrm{C}$ although this product was clearly formed in membranes from cells grown at $37^{\circ} \mathrm{C}$. Altogether, these results suggest that at $55^{\circ} \mathrm{C}$ mannosyltransferases that utilize GDP-Man as the mannose donor for PIM synthesis are inhibited and/or less efficient in catalysing the mannosyltransferase reactions leading to PIMs.

Finally, we analysed the transfer of $\left[{ }^{14} \mathrm{C}\right] \mathrm{Man}$ from GDP- $\left[{ }^{14} \mathrm{C}\right]$ Man to polyprenyl-monophosphate carriers. The PPM synthase from M. tuberculosis is involved in the generation of PPM, which is subsequently utilized as the Man donor in the biosynthesis of LM (lipomannan) and LAM (lipoarabinomannan) (Gurcha et al., 2002). Labelling of membranes from $M$. thermoresistibile grown at $37^{\circ} \mathrm{C}$ with $\mathrm{GDP}-\left[{ }^{14} \mathrm{C}\right]$ Man preferentially generated $\mathrm{C}_{50}$-P-Man in a dose-response fashion, whereas $\mathrm{C}_{35}$-P-Man was barely produced (Fig. 6b). Interestingly, labelling of membranes from cells grown at $55^{\circ} \mathrm{C}$ showed a strong inhibition of $\mathrm{C}_{50}-\mathrm{P}-\mathrm{Man}$ formation, compared to membranes from cells grown at $37^{\circ} \mathrm{C}$. This result suggests that incubation of the cells at high temperature negatively affects PPM synthase activity responsible for $\mathrm{C}_{50}-\mathrm{P}-\mathrm{Man}$ biosynthesis. Since $\mathrm{C}_{50^{-}}$ P-Man is the mannose donor for linear LM and LAM, and utilizes PIM $_{2}$ precursors, it could be argued that the observed in vivo decrease of the $\mathrm{PIM}_{6}$ family at $55^{\circ} \mathrm{C}$ is associated with both a decrease in the synthesis of $\mathrm{PIM}_{2}$ and the $\mathrm{C}_{50}-\mathrm{P}-\mathrm{Man}$ donor. However, it remains to be established whether this decrease in PPM synthase activity affects the production of LM/LAM within M. thermoresistibile cell walls.

\section{DISCUSSION}

One can view the mycobacterial cell wall as an array of distinct lipid molecules, each with its own role in modulating the interaction with its host. Early work by Toriyama et al. $(1978,1980)$ reported the effect of growth temperature on mycolic acid composition and synthesis. It was found that an increase in growth temperature of Mycobacterium phlei leads to an enhanced mean chain length of mycolic acids. Baba et al. (1989) demonstrated that in M. smegmatis, the ratio of $\alpha-, \alpha^{\prime}$ - and epoxymycolates also varies in response to changes in growth temperature. More recently, it was

Fig. 5. Elevated temperature alters complex cellular lipids that are produced in lower quantity at $55^{\circ} \mathrm{C}$. M. thermoresistibile was grown in liquid medium and labelled with $1 \mu \mathrm{Ci}(37 \mathrm{kBq})$ $\left[1,2-{ }^{14} \mathrm{C}\right]$ acetate $\mathrm{ml}^{-1}$. Labelled lipids were extracted as described in Methods. Equal counts (100000 c.p.m. for apolar lipids, and 50000 c.p.m. for polar lipids) for each extract were applied to two-dimensional TLC plates and developed using different solvent systems as described in Methods. DAT, diacylated trehalose; GMM, glycerol monomycolate; MAT, multiacylated trehalose; TDM, trehalose dimycolate; TG, triglyceride; $?$, unassigned product. Autoradiograms were obtained after 3-4 days exposure to Kodak X-Omat AR films. 

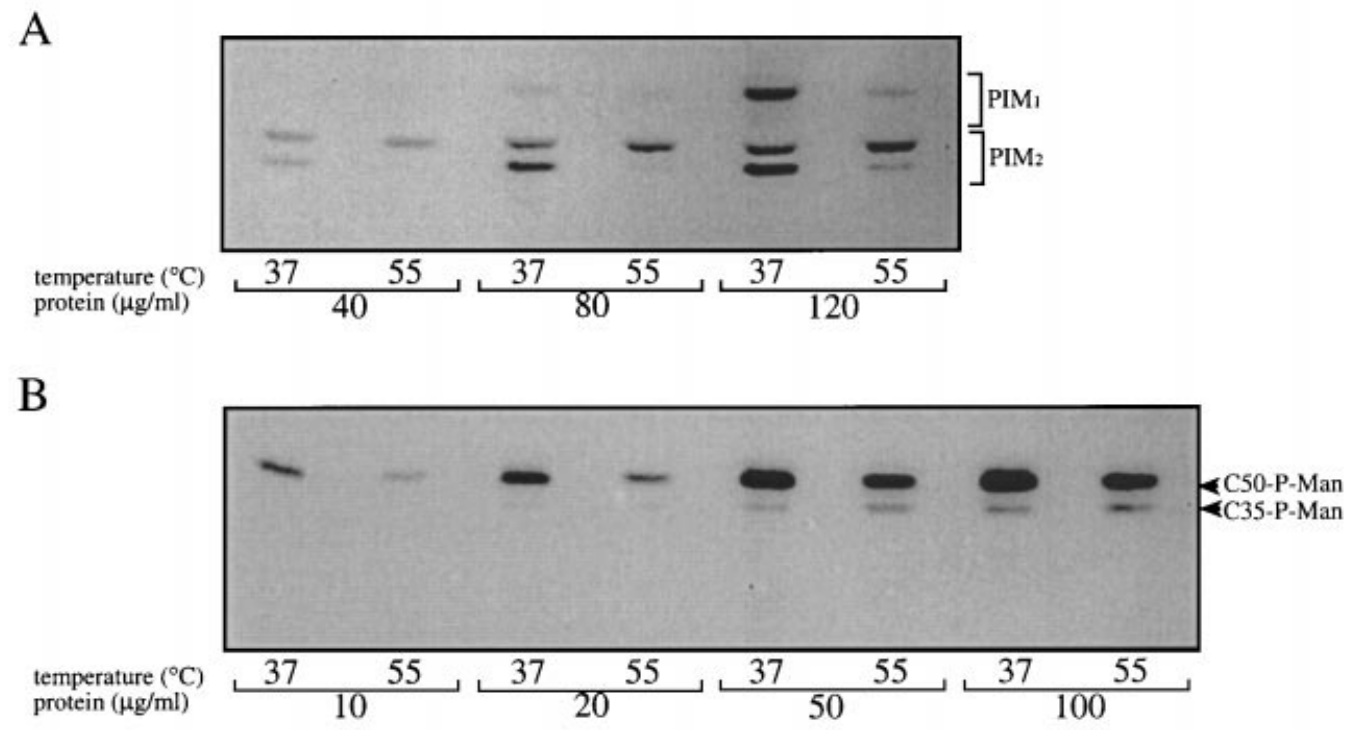

Fig. 6. $\alpha$-Mannosyltransferase activity in $M$. thermoresistibile membrane extracts. (A) TLC/autoradiography of the in situ labelled endogenous PIMs based on the transfer of $\left[{ }^{14} \mathrm{C}\right]$ Man from $\left[{ }^{14} \mathrm{C}\right]$ GDP-Man to PIMs. Mannosyltransferase assays contained increasing concentrations of $M$. thermoresistibile membrane fractions, $\left[{ }^{14} \mathrm{C}\right] \mathrm{GDP}$-Man, as well as amphomycin. After incubation, the reaction was stopped and extraction of $\left[{ }^{14} \mathrm{C}\right] \mathrm{PIMs}$ was performed as described in Methods. Approximately $20 \%$ of the total counts from each assay were applied to TLC and resolved using $\mathrm{CHCl} / \mathrm{CH} \mathrm{H}_{3} \mathrm{OH} / \mathrm{H}_{2} \mathrm{O}$ $\left(65: 25: 4\right.$, by vol.). (B) TLC/autoradiography of the in situ labelled endogenous PPMs $\left(C_{35} / C_{50}-P P M\right)$ based on the transfer of $\left[{ }^{14} \mathrm{C}\right]$ Man from $\left[{ }^{14} \mathrm{C}\right] \mathrm{GDP}-\mathrm{Man}$ to $\mathrm{C}_{35} / \mathrm{C}_{50}$ polyprenol phosphates. Mannosyltransferase assays contained increasing concentrations of membrane proteins. After incubation, the reaction was stopped and $\left[{ }^{14} \mathrm{C}\right] \mathrm{PPMs}$ were extracted. Approximately $20 \%$ of the total counts from each assay reaction were applied to TLC and resolved using $\mathrm{CHCl}_{3} / \mathrm{CH}_{3} \mathrm{OH} / \mathrm{NH}_{4} \mathrm{OH} / \mathrm{H}_{2} \mathrm{O}(65: 25: 0 \cdot 4: 3 \cdot 6$, by vol.). Autoradiograms were obtained after overnight exposure to a Kodak $\mathrm{X}$-Omat film.

demonstrated that a mutant strain of M. tuberculosis that no longer synthesizes oxygenated mycolic acids presents profound envelope permeability alterations and appears strongly attenuated in mice (Dubnau et al., 2000). These observations imply that each subclass composition of mycolic acids is regulated and that the subclasses serve discrete functions. Therefore, genes involved in mycolic acid metabolism, and those involved in modification of the mero chain and elongation steps, may be tightly regulated. In this study, we report a temperature-dependent down-regulation of KasA, an enzyme directly involved in the elongation process of the meromycolate chain by condensing malonyl-AcpM with a growing acyl-AcpM chain (Schaeffer et al., 2001; Kremer et al., 2002a). The decrease in KasA expression correlates with a reduction in mycolic acid biosynthetic activity as evidenced by the lower production of mycolates in M. thermoresistibile cells grown at $55^{\circ} \mathrm{C}$.

The mycolic acid $S$-adenosylmethionine-dependent methyl transferases are a large family of highly homologous proteins that modify olefinic mycolic acids with cyclopropane rings and methyl branches. The three classes of mycolates, $\alpha$-, methoxy- and ketomycolates, are all modified with cyclopropane rings and methyl branches within their mero chain. One of these transferases, PcaA, has been shown as essential for M. tuberculosis pathogenesis, since a pcaA mutant failed to establish a chronic persistent $M$. tuberculosis infection in mice (Glickman et al., 2000). PcaA is required for the synthesis of the proximal cyclopropane ring of $\alpha$-mycolates. It was subsequently shown that CmaA2, another cyclopropane synthase, is required for the synthesis of the trans cyclopropane rings of both methoxy- and ketomycolates (Glickman et al., 2001). Inactivation of $\mathrm{cmaA} 2$ causes accumulation of unsaturated derivatives of both methoxy- and ketomycolates (Glickman et al., 2001). We show here that elevated growth temperatures significantly affect the distribution of the different mycolic acid subclasses. Basically, growth at $55^{\circ} \mathrm{C}$ causes accumulation of unsaturated derivatives of both $\alpha$ - and methoxymycolates as well as loss of trans-containing olefins corresponding to oxygenated mycolic acids. It is therefore tempting to speculate that temperature-dependent inhibition of mycolic acid cyclopropane synthases results in the accumulation of unsaturated mycolic acids. In this regard, recent work has demonstrated that the cyclopropane fatty acid synthase from E. coli that catalyses cyclopropanation of fatty acids is a short-lived protein in vivo and its degradation is dependent on expression of the heat-shock regulon (Chang et al., 2000). However, whether PcaA, CmaA2 or other mycobacterial cyclopropane synthases are regulated by temperature remains to be established. In addition, differences in the geometrical position of the centre (cis-olefin, trans-olefin or 
-cyclopropane) may directly affect cell-wall fluidity. Overexpression of CmaA2 in M. smegmatis was shown to be associated with an increase in the melting temperature of the cell wall (George et al., 1995). It has therefore been suggested that cyclopropanation of the proximal double bond decreases fluidity of the cell wall. In addition, cyclopropanated fatty acids are intermediate in fluidity between the more fluid cis-olefin and the less fluid trans-olefin as measured by differential scanning calorimetry (Silvius \& McElhaney, 1979). Thus, accumulation of cis-olefins as a consequence of cyclopropanation inhibition may represent a strategy used by mycobacteria to increase cell-wall fluidity.

In addition to KasA, the expression of the mycobacterial Ag85 complex was also reduced in cells cultivated at $55^{\circ} \mathrm{C}$. In M. tuberculosis, Ag85A (FbpA), Ag85B (FbpB) and $\mathrm{Ag} 85 \mathrm{C} 2$ (FbpC2) represent the three dominant exported proteins. By means of their fibronectin-binding activity, these proteins are supposed to be involved in the pathogenesis of tuberculosis. They have also recently been suggested to play a role in the final assembly of the mycobacterial cell wall by catalysing the transfer of mycolic acids to trehalose, to generate TDM and to the cell-wall AG (Belisle et al., 1997; Kremer et al., 2002b). The decreased expression of the Ag85 complex is consistent with the observation that cells cultivated at $55^{\circ} \mathrm{C}$ produce less TDM than cells grown at $37^{\circ} \mathrm{C}$, as evidenced by two-dimensional TLC analysis of complex lipids. Altogether, our results suggest that the expression level of various enzymes involved in fatty acid/mycolic acid metabolism is regulated by temperature, thus participating in the environmental adaptation of the bacilli. Consistent with this notion, we have observed that the cytosolic enzyme fraction, which contains FAS-I and FAS-II, from cells grown at $55^{\circ} \mathrm{C}$ presents a distinct electrophoretic profile different from that of the corresponding fraction from cells grown at $37^{\circ} \mathrm{C}$ (data not shown). Whether the proteins that are down- or upregulated at $55^{\circ} \mathrm{C}$ belong to the FAS-II system remains to be investigated.

PIMs that are known to be precursors of LM and LAM have been proposed to recruit natural killer $\mathrm{T}$ cells which play a primary role in the granulomatous response (Apostolou et al., 1999; Gilleron et al., 2001). Moreover, a role for surface-exposed PIMs as M. tuberculosis adhesins that mediate attachment to non-phagocytic cells has also been established (Hoppe et al., 1997). A recent study demonstrated a novel interaction between PIMs and Galectin-3, a galactoside-binding protein of macrophages (Beatty et al., 2002), suggesting a role of these glycolipids in mycobacterial virulence. Our study shows that at elevated temperature both $\mathrm{Ac}_{4} \mathrm{PIM}_{6}$ and $\mathrm{Ac}_{3} \mathrm{PIM}_{6}$ synthesis is reduced, whereas expression of the other PIMs remains unchanged. This may be explained, at least partially, by a reduced mannosyltransferase activity as suggested by a decrease of GDP- $\left[{ }^{14} \mathrm{C}\right] \mathrm{Man}$ incorporation into the PIM family using membranes from cells grown at elevated temperature. Although a clear function of $\mathrm{PIM}_{6}$ has not yet been assigned, its reduced expression may reflect significant changes in cell-wall fluidity and permeability. In addition, in vitro studies have shown that high temperature negatively affects PPM synthase activity responsible for $\mathrm{C}_{50}-\mathrm{P}-\mathrm{Man}$ synthesis. This glycolipid has previously been shown to be the mannose donor for LM/LAM biosynthesis (Gurcha et al., 2002).

\section{ACKNOWLEDGEMENTS}

We are grateful to Dr K. Huygen for kindly providing antiAg85 antibodies and to Dr P. Bifani for providing the M. thermoresistibile strain. This work was supported by the Centre National de la Recherche scientifique (UMR 8576, Glycobiologie structurale et fonctionelle) and by INSERM. Y.G. holds a fellowship from the Ministère de l'Enseignement Supérieur et de la Recherche. G.S.B. is currently a Lister Institute-Jenner Research Fellow and acknowledges support from the Wellcome Trust and the Medical Research Council.

\section{REFERENCES}

Apostolou, I., Takahama, Y., Belmant, C. \& 9 other authors (1999). Murine natural killer $\mathrm{T}$ (NKT) cells contribute to the granulomatous reaction caused by mycobacterial cell walls. Proc Natl Acad Sci U S A 96, 5141-5146.

Baba, T., Kaneda, K., Kusunose, E., Kusunose, M. \& Yano, I. (1989). Thermally adaptive changes of mycolic acids in $\mathrm{Myco-}$ bacterium smegmatis. J Biochem 106, 81-86.

Beatty, W. L., Rhoades, E. R., Ullrich, H. J., Chatterjee, D., Heuser, J. E. \& Russell, D. G. (2000). Trafficking and release of mycobacterial lipids from infected macrophages. Traffic 1, 235-247.

Beatty, W. L., Rhoades, E. R., Hsu, D. K., Liu, F. T. \& Russell, D. G. (2002). Association of a macrophage galactoside-binding protein with Mycobacterium-containing phagosomes. Cell Microbiol 4, 167-176.

Bekierkunst, A. (1968). Acute granulomatous response produced in mice by trehalose-6,6'-dimycolate. J Bacteriol 96, 958-961.

Belisle, J. T., Vissa, V. D., Sievert, T., Takayama, K., Brennan, P. J. \& Besra, G. S. (1997). Role of the major antigen of Mycobacterium tuberculosis in cell wall biogenesis. Science 276, 1420-1422.

Besra, G. S. (1998). Preparation of cell-wall fractions from mycobacteria. Methods Mol Biol 101, 91-107.

Besra, G. S., Morehouse, C. B., Rittner, C. M., Waechter, C. J. \& Brennan, P. J. (1997). Biosynthesis of mycobacterial lipoarabinomannan. J Biol Chem 272, 18460-18466.

Bloch, H. (1950). Studies on the virulence of tubercle bacilli. Isolation and biological properties of a constituent of virulent organisms. J Exp Med 91, 197-218.

Brennan, P. J. \& Nikaido, H. (1995). The envelope of mycobacteria. Annu Rev Biochem 64, 29-63.

Camacho, L. R., Constant, P., Raynaud, C., Lanéelle, M. A., Triccas, J. A., Gicquel, B., Daffé, M. \& Guilhot, C. (2001). Analysis of the phthiocerol dimycocerosate locus of Mycobacterium tuberculosis. J Biol Chem 276, 19845-19854.

Chang, Y. Y., Eichel, J. \& Cronan, J. E., Jr. (2000). Metabolic instability of Escherichia coli cyclopropane fatty acid synthase is due to RpoH-dependent proteolysis. J Bacteriol 182, 4288-4294.

Cole, S. T., Brosch, R., Parkhill, J. \& 39 other authors (1998). Deciphering the biology of Mycobacterium tuberculosis from the complete genome sequence. Nature 393, 537-544. 
Cox, J. S., Chen, B., McNeil, M. \& Jacobs, W. R., Jr (1999). Complex lipid determinates tissue-specific replication of Mycobacterium tuberculosis in mice. Nature 402, 79-83.

Cronan, J. E. (2002). Phospholipid modifications in bacteria. Curr Opin Microbiol 5, 202-205.

Daffé, M. \& Draper, P. (1998). The envelope layers of mycobacteria with reference to their pathogenicity. Adv Microbiol Phys 39, 131-203.

Davidson, L. A., Draper, P. \& Minnikin, D. E. (1982). Studies on the mycolic acids from the walls of Mycobacterium microti. J Gen Microbiol 128, 823-828.

Dubnau, E., Chan, J., Raynaud, C., Mohan, V. P., Lanéelle, M. A., Yu, K., Quémard, A., Smith, I. \& Daffé, M. (2000). Oxygenated mycolic acids are necessary for virulence of Mycobacterium tuberculosis in mice. Mol Microbiol 36, 630-637.

George, K. M., Yuan, Y., Sherman, D. R. \& Barry, C. E., III (1995). The biosynthesis of cyclopropanated mycolic acids in Mycobacterium tuberculosis. Identification and functional analysis of CMAS-2. J Biol Chem 270, 27292-27298.

Gilleron, M., Ronet, C., Mempel, M., Monsarrat, B., Gachelin, G. \& Puzo, G. (2001). Acylation state of the phosphatidylinositol mannosides from Mycobacterium bovis Calmette Guérin and ability to induce granuloma and recruit natural killer $\mathrm{T}$ cells. J Biol Chem 276, 34896-34904.

Glickman, M. S., Cox, J. S. \& Jacobs, W. R., Jr (2000). A novel mycolic acid cyclopropane synthetase is required for cording, persistence, and virulence of Mycobacterium tuberculosis. Mol Cell 5, 717-727.

Glickman, M. S., Cahill, S. M. \& Jacobs, W. R., Jr (2001). The Mycobacterium tuberculosis cmaA2 gene encodes a mycolic acid trans-cyclopropane synthetase. J Biol Chem 276, 2228-2233.

Gurcha, S. S., Baulard, A. R., Kremer, L. \& 7 other authors (2002). Ppm1, a novel polyprenol monophosphomannose synthase from Mycobacterium tuberculosis. Biochem J 365, 441-450.

Hoppe, H. C., De Wet, B. J. M., Cywes, C., Daffé, M. \& Ehlers, M. R. W. (1997). Identification of phosphatidylinositol mannoside as a mycobacterial adhesin mediating both direct and opsonic binding to nonphagocytic mammalian cells. Infect Immun $\mathbf{6 5}$, 3896-3905.

Huygen, K., Lozes, E., Gilles, B. \& 10 other authors (1994). Mapping of TH1 helper T-cell epitopes on major secreted mycobacterial antigen $85 \mathrm{~A}$ in mice infected with live Mycobacterium bovis BCG. Infect Immun 62, 363-370.

Kikuchi, S., Rainwater, D. L. \& Kolattukudy, P. E. (1992). Purification and characterization of an unusually large fatty acid synthase from Mycobacterium tuberculosis var. bovis BCG. Arch Biochem Biophys 295, 318-326.

Kremer, L., Baulard, A., Estaquier, J., Content, J., Capron, A. \& Locht, C. (1995). Analysis of the Mycobacterium tuberculosis 85A Antigen promoter region. J Bacteriol 177, 642-653.

Kremer, L., Baulard, A. R. \& Besra, G. S. (2000). Genetics of mycolic acid biosynthesis. In Molecular Genetics of Mycobacteria, pp. 173-190. Edited by G. F. Hatfull \& W. R. Jacobs, Jr. Washington, DC: American Society for Microbiology.
Kremer, L., Dover, L., Carrère, S. \& 7 other authors (2002a). Mycolic acid biosynthesis and enzymatic characterization of the beta-ketoacyl-ACP synthase A-condensing enzyme from $\mathrm{Myco-}$ bacterium tuberculosis. Biochem J 364, 423-430.

Kremer, L., Maughan, W. N., Wilson, R. A., Dover, L. G. \& Besra, G. S. (2002b). The M. tuberculosis antigen 85 complex and mycolyltransferase activity. Lett Appl Microbiol 34, 233-237.

Laemmli, U. K. (1970). Cleavage of structural proteins during the assembly of the head of bacteriophage T4. Nature 227, 680-685.

Levy-Frebault, V., Daffé, M., Restrepo, E., Grimont, F., Grimont, P. A. \& David, H. L. (1986). Differentiation of Mycobacterium thermoresistibile from Mycobacterium phlei and other rapidly growing mycobacteria. Ann Inst Pasteur Microbiol 137A, 143151.

Magnuson, K., Jackowski, S., Rock, C. O. \& Cronan, J. E., Jr (1993). Regulation of fatty acid biosynthesis in Escherichia coli. Microbiol Rev 57, 522-542.

Marr, A. G. \& Ingrahm, J. L. (1962). Effect of temperature on the composition of fatty acids in Escherichia coli. J Bacteriol 84, 1260-1267.

Minnikin, D. E. (1982). Lipids: complex lipids, their chemistry, biosynthesis and roles. In The Biology of the Mycobacteria, pp. 95-184. Edited by C. Ratledge \& J. Stanford. London: Academic Press.

Peterson, D. O. \& Bloch, K. (1977). Mycobacterium smegmatis fatty acid synthetase: long chain transacylase chain length specificity. J Biol Chem 252, 5735-5739.

Schaeffer, M. L., Agnihotri, G., Volker, C., Kallender, H., Brennan, P. J. \& Lonsdale, J. T. (2001). Purification and biochemical characterization of the Mycobacterium tuberculosis betaketoacyl-acyl carrier protein synthases, KasA and KasB. J Biol Chem 276, 47029-47037.

Silvius, J. R. \& McElhaney, R. N. (1979). Effects of phospholipid acyl chain structure on thermotropic phase properties. 2. Phosphatidylcholines with unsaturated or cyclopropane acyl chains. Chem Phys Lipids 25, 125-134.

Toriyama, S., Yano, I., Masui, M., Kusunose, M. \& Kusunose, E. (1978). Separation of $C_{50-60}$ and $C_{70-80}$ mycolic acid molecular species and their changes by growth temperatures in Mycobacterium phlei. FEBS Lett 95, 111-115.

Toriyama, S., Yano, I., Masui, M., Kusunose, E., Kusunose, M. \& Akimori, N. (1980). Regulation of cell wall mycolic acid biosynthesis in acid-fast bacteria. I. Temperature-induced changes in mycolic acid molecular species and related compounds in Mycobacterium phlei. J Biochem 88, 211-221.

Wiker, H. G. \& Harboe, M. (1992). The antigen 85 complex: a major secretion product of Mycobacterium tuberculosis. Microbiol Rev 56, 648-661.

Yuan, Y., Zhu, Y., Crane, D. D. \& Barry, C. E., III. (1998). The effect of oxygenated mycolic acid composition on cell wall function and macrophage growth in Mycobacterium tuberculosis. Mol Microbiol 29, 1449-1458.

Received 2 May 2002; revised 22 May 2002; accepted 23 May 2002. 